\title{
Short Natural Fibers Reinforced Polyolefin Composites
}

\author{
Zane Zelča ${ }^{1}$, Silvija Kukle², Jānis Kajaks ${ }^{3}$ \\ ${ }^{1,2}$ Institute of Design Technologies, Faculty of Materials Science and Applied Chemistry, Riga Technical \\ University, ${ }^{3}$ Institute of Polymer Materials, Faculty of Materials Science and Applied Chemistry, Riga \\ Technical University
}

\begin{abstract}
- this article summarizes modification techniques of the most popular polyolefin composite reinforced with short natural fibers based on two interface modification strategies: filler modification and matrix modification by additives. According to analysis of published papers, it can be concluded that the fiber pretreatment does not result in higher improvement of the properties compared with adding coupling agent in the compounding process.
\end{abstract}

Keywords - polyolefin composites, natural fibers filler, fibersmatrix interface, filler modification.

\section{INTRODUCTION}

Natural fiber composites based on polyolefins have gained increasing interest over the past two decades in the scientific community and industry.

Numerous strategies to improve the interaction at the fibermatrix interface have been developed and published, with varying success. Incompatibility at the interface limits stress transfer via the interface; reinforcement potential of natural fibers or wood particles cannot be exploited to the full extent, especially for short fibers and different particles.

The hydrophobic polymer matrices can protect the reinforcements from the influence of humidity. A gap between the matrix and reinforcement, as it can often be observed in uncompatibilized filler, acts like a pathway for humidity into the material (1).

The fiber-matrix interaction can be improved either via the fiber, usually by modifying its surface, or via the matrix, usually by employing additives called coupling agents.

There are two interface modification strategies: filler modification and matrix modification by additives.

Frequently used fiber modification methods are silane (2), (5), enzymatic (3), (12), (13), heat (4), (3), esterification (5), (6), mercerization (2), (5), (7), acetylation (5) and acrylation treatment. Several other treatments have been investigated with varying success.

Additives used to improve the fiber-matrix interaction in fiber filler rely on coupling agents, which are added during the compounding in composite production.

Chemicals that have been tested for applicability as coupling agents are: maleic anhydride (7), (9) and various isocyanatefunctionalized polymers (8), stearic acid (10) and titanium (11) coupling agents.

\section{FILLER MODIFICATION METHODS}

\section{A. Mercerization}

Mercerization reduces the lignin and hemicellulose content and also tends to increase the surface roughness of fibers. Cellulose fibrillation increases the surface available for fibermatrix interaction and potentially improves the filler properties of the composites (Fig. 1).
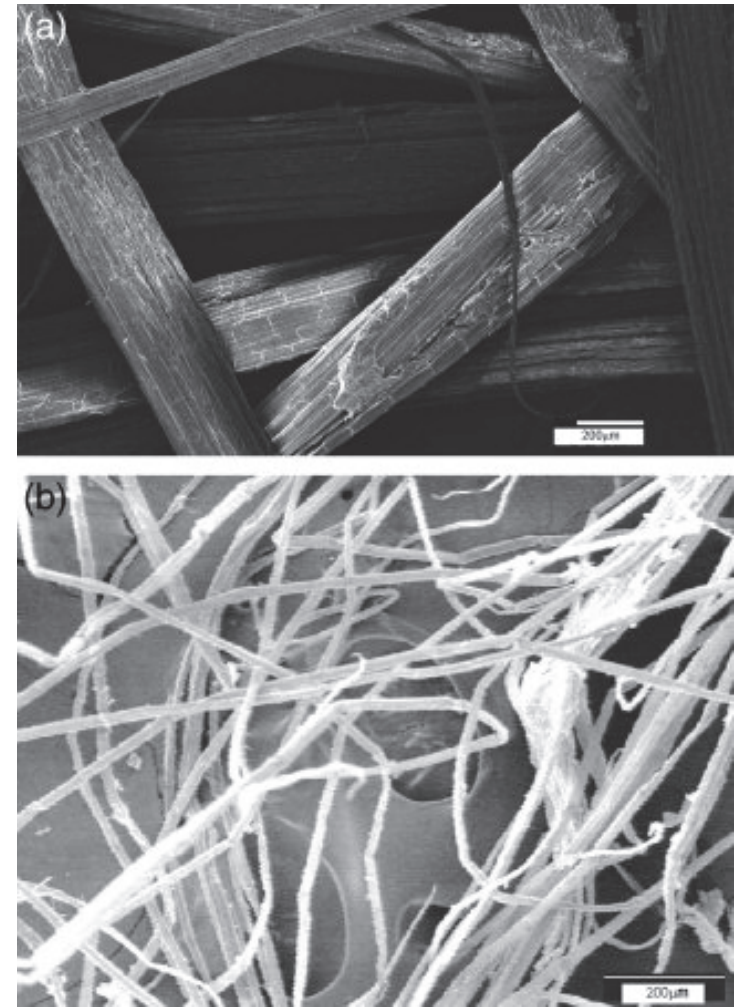

Fig. 1. SEM of raw oil palm fiber; (a) SEM of mercerized microfiber (b) (19).

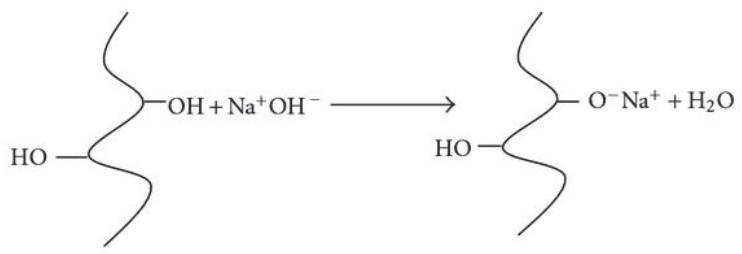

Fig. 2. Alkalization (2) 
$\mathrm{NaOH}$ pretreatment might be a useful first step in combination with other fiber or matrix modification method (Fig. 2). Alkalization process changes the structure of the native cellulose I to cellulose II.

\section{B. Silane Treatment}

The fiber/filler pretreatment conditions are adapted to the chemical structure of silane. Application is performed in organic-based solvents, such as acetone acetic acid, carbon tetrachloride, methanol/water, ethanol/water or ethanol and water-based solvents. Alkaline pretreatment of the fiber/filler can be done prior to the silane one. Silane fiber treatment in combination with maleic anhydride grafted polypropylene improves mechanical properties of the composite. The silanization reaction schemes are given below (5).

$$
\begin{aligned}
& \mathrm{CH}_{2} \mathrm{CHSi}(\mathrm{OH})_{3}+\text { Fiber }-\mathrm{OH} \\
& \quad \rightarrow \mathrm{CH}_{2} \mathrm{CHSi}(\mathrm{OH})_{2} \mathrm{O}-\text { Fiber }+\mathrm{H}_{2} \mathrm{O}
\end{aligned}
$$

Nano-scaled silica species, which are suitable for penetration the cell walls of the fiber pores synthesized by sol-gel method, can be used (Fig. 3 and Fig. 4).

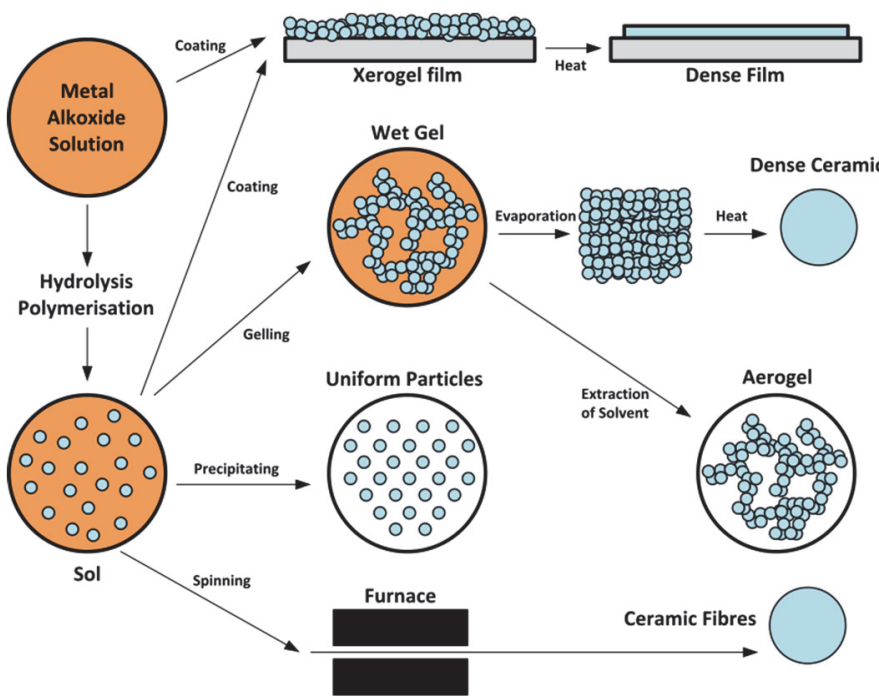

Fig. 3. Schematic representation of the different stages and routes of the sol-gel technology (17).

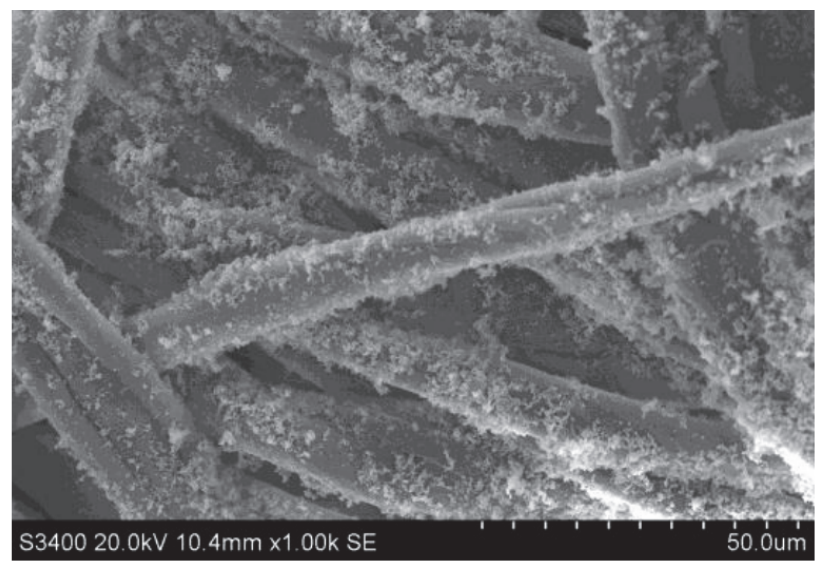

Fig. 4. Sol-gel modified cotton fibers (20).
Two chemical modification methods reported by Brostow et. al. have been used for wood sawdust treatment to improve compatibility between matrix and filler using traditional silane coupling and sol-gel method as second step (18).

\section{Acetylation}

Acetylation is usually performed using acetic anhydride, acetyl chloride, ketene (Fig. 5). Acetylation of fibers reduces water absorption of composite, has some potential to increase mechanical properties, and is being applied industrially to wood materials.
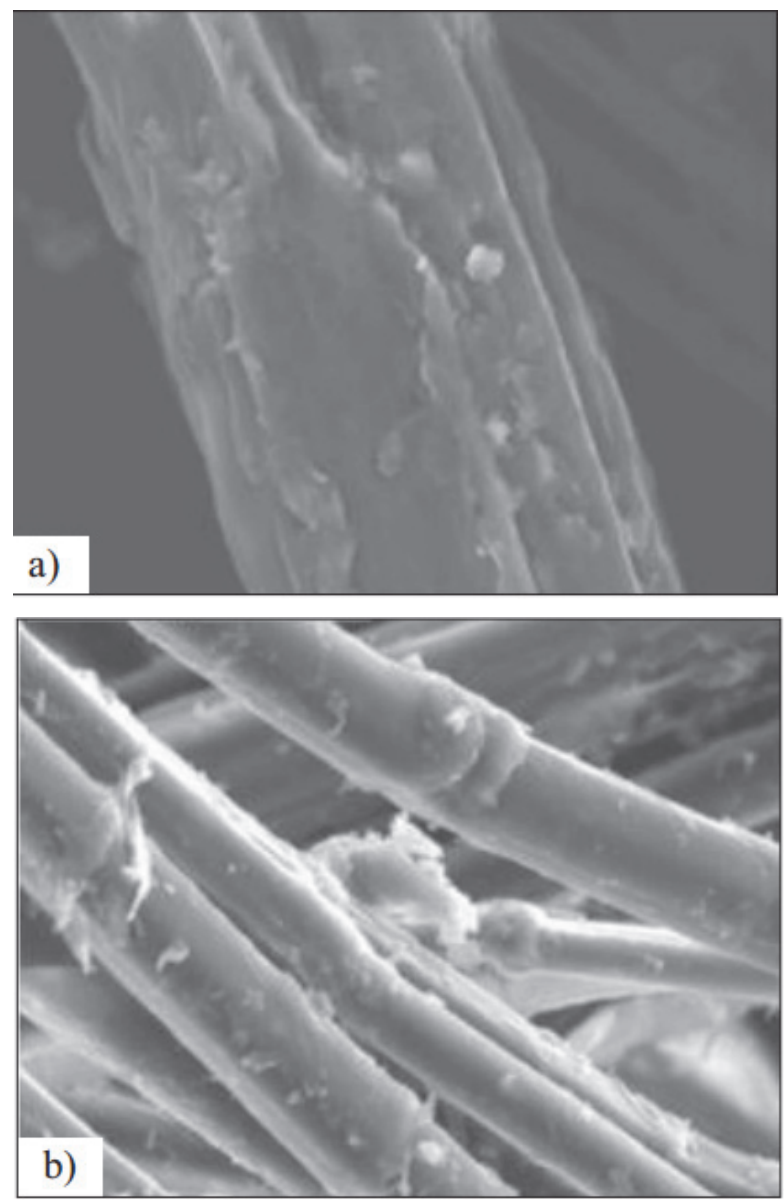

Fig. 5. Untreated hemp fiber (a) and acetylated hemp fibers (b) (21).

The acetylation reaction scheme is given below (4).

$$
\begin{array}{r}
\text { Fiber }-\mathrm{OH}+\mathrm{CH}_{3}-\mathrm{C}(=\mathrm{O})-\mathrm{O}-\mathrm{C}(=\mathrm{O})-\mathrm{CH}_{3} \\
\rightarrow \text { Fiber }-\mathrm{OCOCH}_{3}+\mathrm{CH}_{3} \mathrm{COOH}
\end{array}
$$

\section{Esterification}

To increase chemical compatibility between natural fibers and polyolefins, maleic anhydride can be applied (6). The objective of this approach is the reaction of hydroxyl groups of hemicelluloses and lignin with acetic anhydride, forming esters, thus reducing its hydrophilicity (Fig. 6). 
<smiles>CCCCC(O)CC</smiles>

Fig. 6. Esterification (14).

\section{E. Enzymes}

Enzymes are macromolecular biological catalysts widely used in many industries including pulp and paper and been extremely attractive "green" technologies (14). Enzyme (fungamix) in demineralized water with $\mathrm{pH} 7.5$ was used. The tensile strength of modified abaca composites was found to be increased by $5-45 \%$ due to the modification (13). Enzyme use is usually combined with some of the matrix modification techniques (Fig. 7).

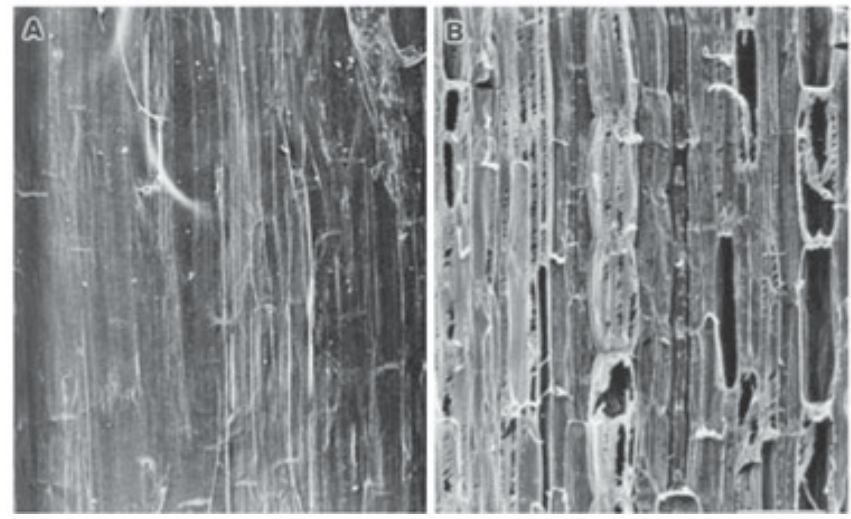

Fig. 7. Natural fibers untreated (A) and after enzyme treatment (B) (14).

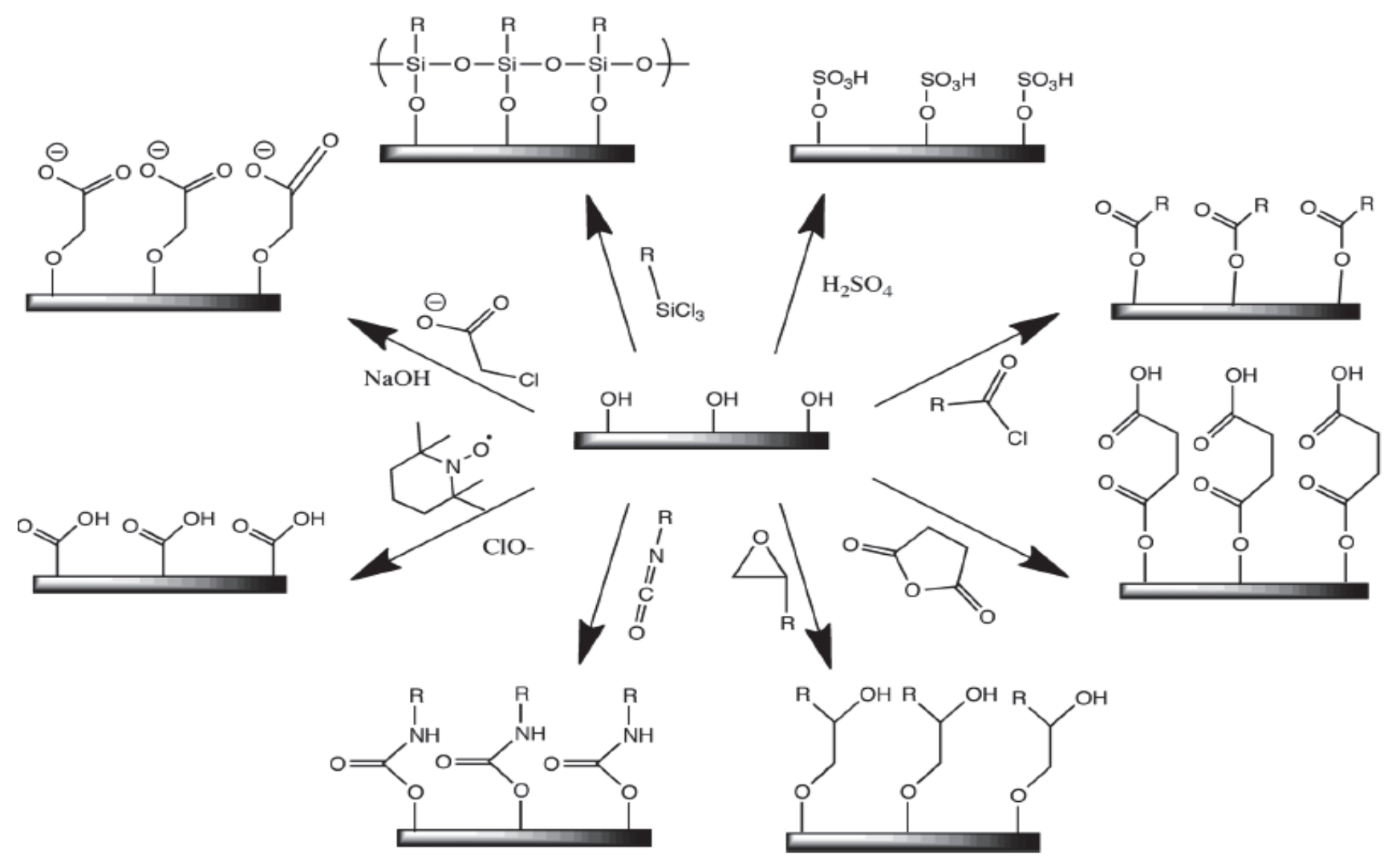

Other strategies reported in the literature aimed to improve the fiber-matrix interaction are: paper wet-strength additive (Kymene), stearic acid [10], acrylic acid and benzoyl chloride, potassium permanganate and toluene-2,4-diisocyanate, polymethylene (polyphenyl isocyanate) and polymeric methylene diphenyl diisocyanate, m-phenylene bismaleimide, bleaching (sodium hypochlorite treatment), octanoyl chloride, O-hydroxybenzene diazonium salt (6).

Common modification chemistries of natural fiber surfaces are: sulfuric acid treatment (provides sulfate esters), carboxylic acid halides and acid anhydrides (create ester linkages), epoxides (also create ether linkages), isocyanates (create urethane linkages), halogenated acetic acids (create carboxymethyl cellulose surfaces), and chlorosilanes (create an oligomeric silylated layer), Fig. 8 (23).

\section{MATRIX MODIFICATION METHODS}

\section{A. Maleic Anhydride Grafted Polyolefins as Matrix Additives}

Matrix based strategies for improving the fiber-matrix interaction in fiber filled composites rely on so-called coupling agents which are simply added during the compounding step in composite production. In most cases these coupling agents are functionalized polymers with a backbone that should be compatible with the matrix, and functional groups grafted to this backbone that can interact with the filler (6).

Maleic anhydride two-part molecules polar groups create chemical bond with natural fiber substrate (Fig. 9 and Fig. 10).

\section{F. Other Filler Modification Strategies}

Fig. 8. Modification chemistries of filler surfaces (23). 

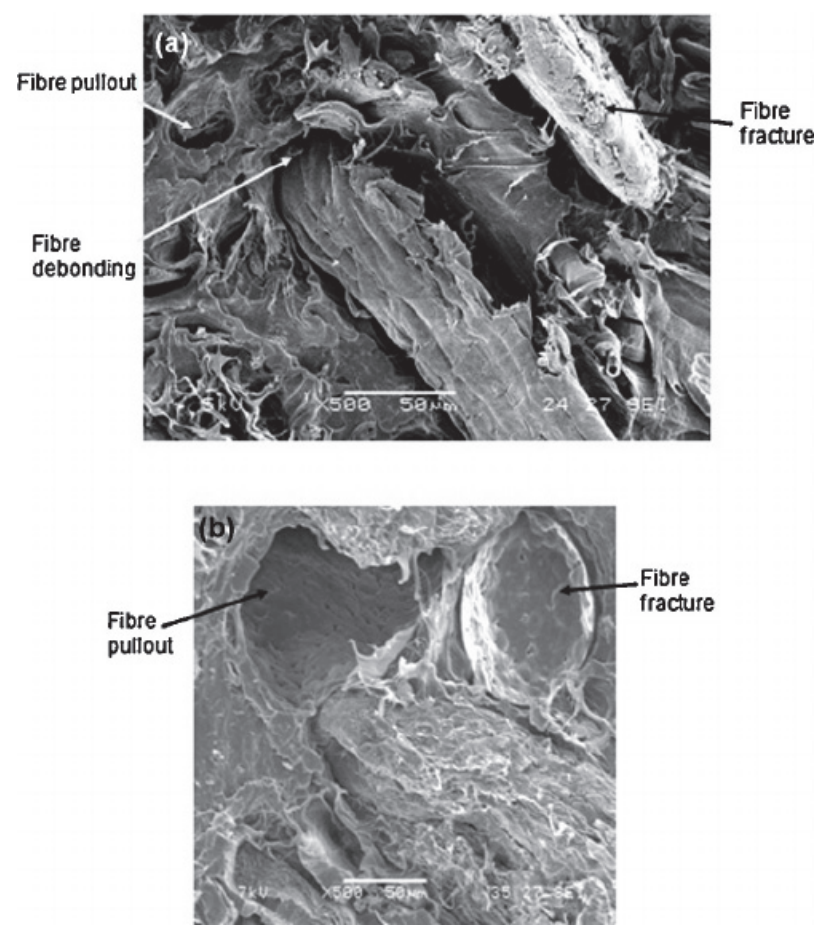

Fig. 9. Composite of durian skin fiber/PP composite without MAPP (a) and (b) with MAPP (22)

\section{B. Isocyanate Functionalized Polymers as Additives}

The isocyanate functionalized polymers are less effective compatibilizers to improve mechanical properties of natural fiber composites than maleic anhydride grafting (Fig. 11) (6). These two classes of coupling agents can be combined with effects at least partly adding up.

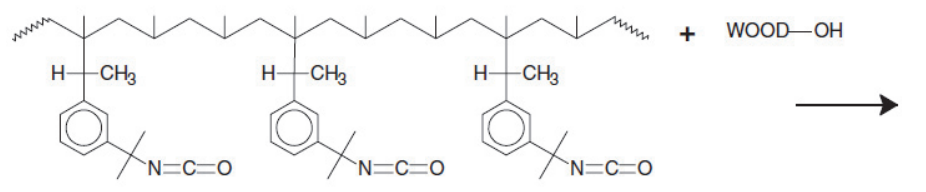

m-TMl-grafted-Polypropylene

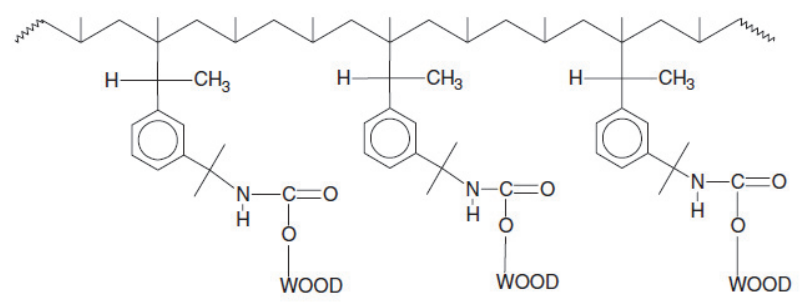

Fig. 11. Coupling mechanism of $\mathrm{m}$-isopropenyl-a,a-dimethylbenzyl-isocyanate grafted polypropylene (15).
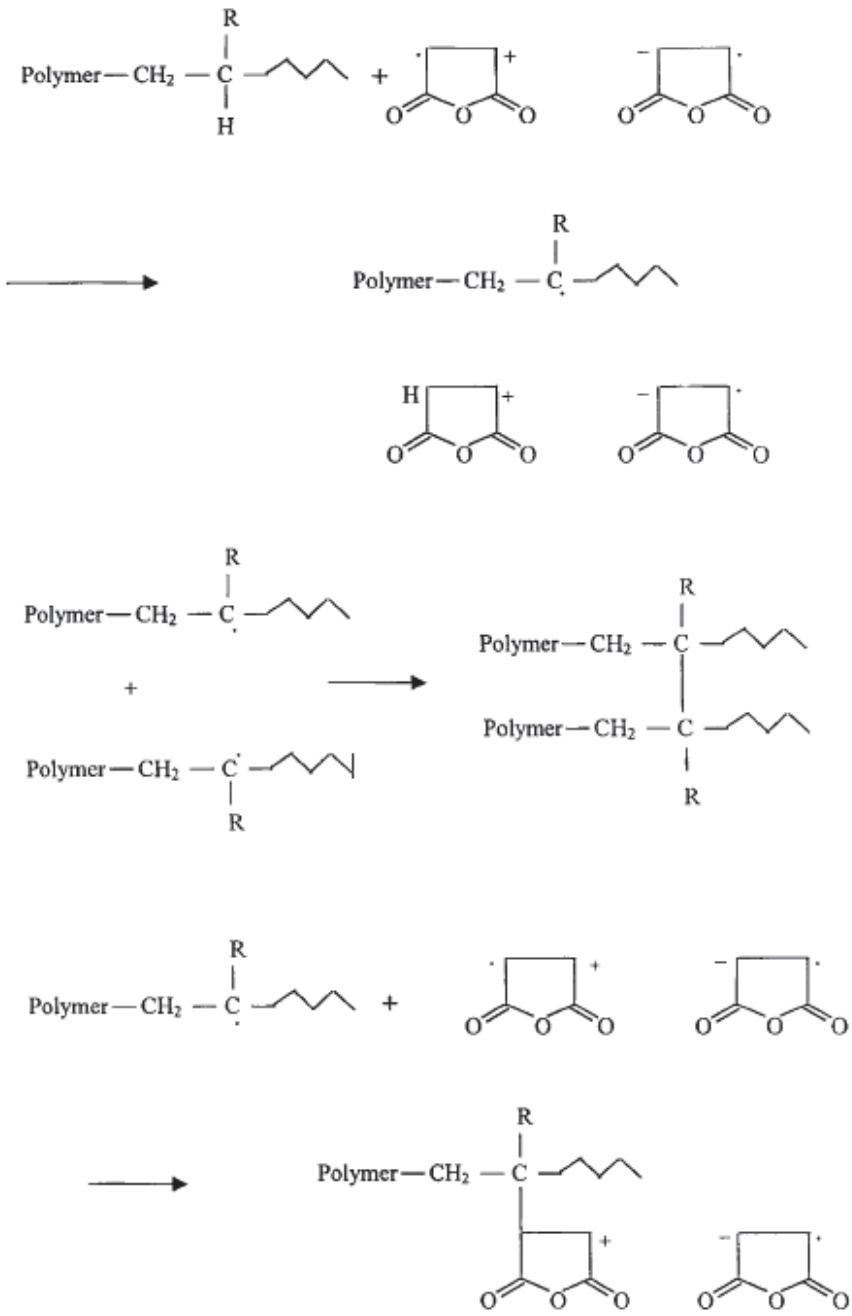

Fig. 10. Mechanism for maleic anhydride grafting of polyethylene (6).

\section{Other Matrix Modification Strategies}

Other strategies reported in the literature are functionalized polymers - oxidized polyolefins, carboxylated polyolefins, acrylic acid functionalized polyolefins, polymeric methylene diphenyl diisocyanate, vinyl-triethoxysilane modified polyolefins, polymer coupling agent m-isopropenyl-a, a-dimethylbenzyl-isocyanate, glycidyl methacrylate grafted polyolefins (6).

\section{CONCLUSION}

The most investigated and also to have proven efficient in polyolefin filled composites are: silanes, maleic anhydride (applied to the fiber), mercerization (often just as a first pretreatment step) and acetylation. Fiber modification strategies require a pretreatment of the filler before composite preparing.

Maleic anhydride grafted polyolefins as matrix additives are proven to increase tensile and flexural strength and to reduce water absorption. The fiber pretreatment does not result in higher improvement of properties compared with the coupling agent added in the compounding process.

In several articles, the highest results were obtained by combining more than one interface modification strategy. 


\section{REFERENCES}

1. Espert, A., Vilaplana, F., Karlsson, S. Comparison of water absorption in natural cellulosic fibres from wood and one-year crops in polypropylene composites and its influence on their mechanical properties, Compos. A 2004, 35, 1267. https://doi.org/10.1016/j.compositesa.2004.04.004

2. Lee, S. Y., Chun, S. J.; Doh, G. H.; Kang, I. A.; Lee, S.; Paik, K. H. J. Influence of Chemical Modification and Filler Loading on Fundamenta Properties of Bamboo Fibers Reinforced Polypropylene Composites. Compos. Mater. 2009, 43, 1639.

https://doi.org/10.1177/0021998309339352

3. Mussig, J. Industrial Applications of Natural Fibres, Structure, Properties and Technical Applications, 2010, 564 p.

4. Kaboorani, A.; Faezipour, M.; Ebrahimi, G. J. Feasibility of Using Heat Treated Wood in Wood/Thermoplastic CompositesReinf. Plast. Compos. 2008, 27, 1689. https://doi.org/10.1177/0731684407084207

5. Xue Li, Lope G. Tabil, Satyanarayan Panigrahi. Chemical Treatments of Natural Fiber for Use in Natural, J Polym Environ 2007, 15, pp. 25-33. https://doi.org/10.1007/s10924-006-0042-3

6. Sobczak, L., Brüggemann, O., Putz, R. F. Polyolefin composites with natural fibers and wood-modification of the fiber/filler-matrix interaction, 2013, 127, 1, pp. 1-17.

7. Isac, S. Maleic Anhydride grafting of polyethylene [Online]. [Accessed 24.11.2016.]. Available: http://shodhganga.inflibnet.ac. in/bitstream/10603/ 2953/11/11 chapter\%205.pdf

8. Pickering, K. L., Ji, C. The effect of poly[methylene(polyphenyl isocyanate)] and maleated polypropylene coupling agents on New Zealand radiata pine fiber-polypropylene composites. Journal of Reinforced Plastics and composites 2004, 23, 18, pp. 2011-2024. https://doi.org/10.1177/0731684404041139

9. Etaati, A., Pather, S., Rahman, M., Wang, H. Ground Hemp Fibers as Filler/reinforcement for Termoplastic Biocomposites, Advances in material Science and Engineering, 2015, 11 p.

10. Stark, N, M. Wood fiber derived from scrap pallets used in polypropylene composites. Forest Products Journal, 49, 6 1999, pp. 39-46.

11. Lei, Y., Wu, Q., Yao, F., Xu, Y. Preparation and properties of recycled HDPE/natural fiber composites, Composites Part A - Applied Science and Manufacturing, 38, 7, 2007, pp. 1664-1674.

12. Lee, Y., Delille, K., Bismarck, A. Greener Surface Treatments of Natura Fibres for the Production of Renewable Composite Materials Cellulose Fibers: Bio - and Nano - Polymer Composites: Green Chemistry and Technology Kalia S, Kaith B S, Kaur I, - Berlin: Springer, 2011, pp 156 158.

13. Bledzki, A. K., Mamun, A. A., Jaszkiewicz, A., Erdmann, K. Polypropylene composites with enzyme modified abaca fibre, Composites Science and Technology 70, 2010, pp. 854-860. https://doi.org/10.1016/j.compscitech.2010.02.003

14. Modifying the Quality of Fiber with Enzymes [Online]. [Accessed 25.11.2016.]. Available: http://www.paperage.com/issues/sept_oct2009/ 09_2009 refining_enzymes.pdf

15. Karmarkar, A., Chauhan, S. S., Modak, J, M. Chanda, Mechanical properties of wood-fiber reinforced polypropylene composites: Effect of a novel compatibilizer with isocyanate functional group. Composites: Part A 38,2007 , pp. 227-233. https://doi.org/10.1016/j.compositesa.2006.05.005

16. SilagePro. American Farm Products [Online]. [Accessed 25.11.2016.] Available: http://afpltd.net/silagepro/

17. Sol-Gel Scheme.svg [Online]. [Accessed 25.11.2016.]. Available: https://commons.wikimedia.org/wiki/File:Sol-Gel_Scheme.svg

18. Brostow, W., Datashvili, T., Jiang, P., Miller, H. Recycled HDPE reinforced with sol-gel silica modified wood sawdust, European Polymer Journal, 76, 2016, pp. 28-39.

https://doi.org/10.1016/j.eurpolymj.2016.01.015
19. Shaji, J., Sreekuma,r P.A., Kenny, J. M., Puglia, D., Thomas, S., Kuruvilla, J. Oil palm microcomposites: Processing and mechanical behavior. Polymer Engineering and Science, 50, 2010, pp. 1853-1863. https://doi.org/10.1002/pen.21699

20. Vihodceva, S., Kukle, S. Dipping Time Influence on the UV Properties of Natural Textiles Treated via Sol-gel Method. No: Proceedings of the International Conference. Nanomaterials: Applications and Properties. (NAP-2013), Ukraina, Alushta, 16-21September, 2013. Sumy State University, 2013, pp. 1.-4.

21. The chemically treated hemp fibres to reinforce polymers [Online]. [Accessed 25.11.2016.]. Available: http://www.tworzywa.pwr.wroc.pl/ pdf/artykuly/article Polimery2011 Kaczmar Pach Burgstaller.pdf

22. Aimi, N. N, Anuar, H., Manshor, M.R., Wan Nazri, W.B., Sapuan, S.M. Optimizing the parameters in durian skin fiber reinforcedpolypropylene composites by response surface methodology, Industrial Crops and Products, 54, 2014, pp. 291-295. https://doi.org/10.1016/i.indcrop.2014.01.016

23. Moon, R. J., Martini, A., Nairn, J., Simonsen, J., Youngblood, J. Cellulose nanomaterials review: structure, properties and nanocomposites, Chem. Soc. Rev., 2011, 40, pp. 3941-3994. https://doi.org/10.1039/c0cs00108b

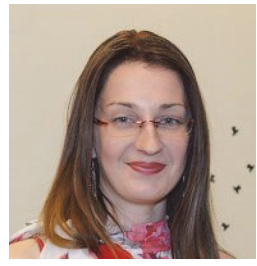

Zane Zelča received a Master's degree in Technology and Design from the Institute of Design Technology of RTU in 2014. She is a doctoral student with the Institute of Design Technology, RTU, and a study specialist at the Department of Design and Material Technology, Institute of Design Technology, Faculty of Materials Science and Applied Chemistry, RTU and a researcher in the Institute of Design Technology of Riga Technical University.

Address: Institute of Design Technologies, Riga Technical University, Kiipsalas iela 6, Riga, LV-1048, Latvia.

E-mail: zane.zelca@rtu.lv

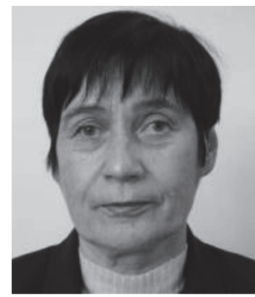

Silvija Kukle is a Professor with the Institute of Design Technologies of RTU. She received the qualification of Engineer Technologist in 1965. In 1977 she received the degree of Candidate of Technical Sciences. In 1991, she received the Doctora degree in Engineering Science. She obtained the Dr. habil. sc. ing. degree in 1993 and has been a Professor since 1994. She is Head of the Department of Technology and Design.

Address: Institute of Design Technologies, Riga Technical University, Kiipsalas iela 6, Riga, LV-1048, Latvia.

E-mail: Silvija.kukle@rtu.lv

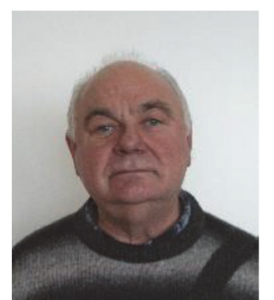

Jānis Kajaks received the Doctoral degree in Engineering Science in 1978 from Riga Polytechnica Institute. He received the qualification of Engineer Technologist in Plastic Processing Technology in 1969. From $1969-1984$, he worked as a lecturer at the Department of Polymer Processing Technology of Riga Polytechnical Institute. Since 2007, he has been an Associate Professor with the Institute of Polymer Materials and the Department of Technology of Polymer Materials of RTU.

Address: Faculty of Material Science and Applied Chemistry, Riga Technica University, P. Valdena iela 3/7, Riga, LV-1048, Latvia.

E-mail: kajaks@ktf.rtu.lv 
Zane Zelča, Silvija Kukle, Jānis Kajaks. Poliolefinu kompozīti ar dabisku īšškiedru pildvielu.

Rakstā apskatītas populārākās uz poliolefīnu bāzes veidotu kompozītu, kas pildīiti ar ̄̄sām dabiskām škiedrām, modifikācijas metodes, izmantojot divas atškirīgas stratēgijas: pildvielas virsmas ḳimisko apstrādi un matricas modificēšanu, izmantojot piedevas. Izanalizējot pieejamās publikācijas, var secināt, ka šķiedru priekšapstrāde nedod kompozītam lielāku īpašību uzlabošanos salīdzinājumā ar starpfāžu modifikatoru pievienošanu maisījumā. Abu stratēǵiju kombinācija nodrošina augstākus mehāniskos rādītājus un labākus ūdens absorbcijas rezultātus. Atkarībā no pildvielas veida var atškirties kīmiskās apstrādes efektivitāte un iegūtā kompozīta īpašības.

Зане Зелча, Силвия Кукле, Янис Каякс. Короткие природные полиолефиновые композиты, армированные короткими природными волокнами. В данной статье исследованы популярные методики модификации композитов на базе полиэфринов, наполненных короткими натуральними волокнами. Исследованы две различные стратегии: химическая обработка поверхностей наполнителя и модификация матрицы с использованием примесей. После изучения и анализа доступных публикаций можно прийти к выводу, что предварительная обработка волокна не даёт особенного улучшения по сравнению с добавками смеси межфазных модификаторов. Комбинация двух приведённых стратегий даёт лучшие результаты в плане механических свойств и сорбции воды. В зависимости от вида наполнителя различаются эффективность химической обработки и свойства полученного композита. 